Cahiers $d u$ MONDE RUSSE

\section{Cahiers du monde russe}

Russie - Empire russe - Union soviétique et États indépendants

46/1-2 | 2005

La Russie vers 1550

\title{
Aleksandr nevskii: Hagiography and national biography
}

Anna NAVROTSKAYA

\section{OpenEdition}

\section{Journals}

Édition électronique

URL : https://journals.openedition.org/monderusse/8806

DOI : 10.4000/monderusse.8806

ISSN : $1777-5388$

Éditeur

Éditions de l'EHESS

Édition imprimée

Date de publication : 1 janvier 2005

Pagination : 297-304

ISBN : 2-7132-2055-6

ISSN : $1252-6576$

Référence électronique

Anna NAVROTSKAYA, "Aleksandr nevskii: Hagiography and national biography », Cahiers du monde russe [En ligne], 46/1-2 | 2005, mis en ligne le 01 janvier 2007, consulté le 04 septembre 2022. URL : http://journals.openedition.org/monderusse/8806 ; DOI : https://doi.org/10.4000/monderusse.8806 
chercher : repérer : avancer

Cet article est disponible en ligne à l'adresse :

http://www.cairn.info/article.php?ID REVUE=CMR\&ID NUMPUBLIE=CMR 461\&ID ARTICLE=CMR 4610297

\title{
Aleksandr nevskii: Hagiography and national biography
}

\author{
par Anna NAVROTSKAYA
}

\section{Editions de l'EHESS | Cahiers du monde russe}

\author{
2005/1-2 - Vol 46 \\ ISSN 1252-6576 | ISBN 2713220556 | pages 297 à 304
}

Pour citer cet article :

-NAVROTSKAYA A., Aleksandr nevskii: Hagiography and national biography, Cahiers du monde russe 2005/ 1-2, Vol 46, p. $297-304$

Distribution électronique Cairn pour les Editions de l'EHESS.

(C) Editions de l'EHESS. Tous droits réservés pour tous pays.

La reproduction ou représentation de cet article, notamment par photocopie, n'est autorisée que dans les limites des conditions générales d'utilisation du site ou, le cas échéant, des conditions générales de la licence souscrite par votre établissement. Toute autre reproduction ou représentation, en tout ou partie, sous quelque forme et de quelque manière que ce soit, est interdite sauf accord préalable et écrit de l'éditeur, en dehors des cas prévus par la législation en vigueur en France. Il est précisé que son stockage dans une base de données est également interdit. 


\section{ALEKSANDR NEVSKII: HAGIOGRAPHY AND NATIONAL BIOGRAPHY}

In his presentation of national consciousness Anderson identifies three major stages of communal self-determination: religious communities, dynastic realms and the imagined communities of nations. ${ }^{1}$ Any stage does not necessarily completely replace another. In specific combinations of religion, nationalism and state power, all three participate in creating identities. The communal and the individual are inseparable in this process, both reflecting an underlying ethical model. National and religious ethical systems share the same principle of morality; the very same logical circle determines their functionality. The existence of God as a supreme and unequivocal reference is a necessary condition for a religious moral system to exist. The rules of behavior and individual choice are thus defined as radiating from an external authority not subject to human error. The notion of "Nation" can easily replace God as an absolute point of reference, weighing all acts of individual will in terms of the good of the nation. In the nationalist ideology, then, nation is a preexisting condition, into which every human being is inevitably born. It is logical to suppose that the framework for both religious and national ethical systems is essentially the same. Being part of a community, whether as servants of God or as servants of a nation, is synonymous with simply being. In both cases, the existence of a personal identity depends on the successful creation of a communal religious / national identity.

It is evident that in the aforementioned circumstances the question of disseminating "the word of Truth" becomes crucial. The message to be transmitted and the means of communicating it are of vital importance. Among the devices employed for this cause, particular exempla have proven to be a powerful tool. Lives of saints and national heroes are perfectly suited to perform the task; they represent powerful instructive cases with the potential of being transmitted across

1. B. Anderson, Imagined Communities: Reflections on the Origin and Spread of Nationalism, revised ed. (London-New York: Verso, 1983): 22. 
temporal and social barriers. They carry a simple message and yet allow for artistic elaboration. Not surprisingly, hagiography and heroic biography have been used for educational purposes, or in other words, as propagandistic devices in creating and maintaining a community.

The image of Aleksandr Nevskii, as it has been elaborated over the centuries, presents a telling case. This image has long been proposed by Russian historiography as having a deeply rooted place in the national memory. Thus, tracing its evolution can provide us with crucial hints about the structure of such a national memory.

By the end of the seventeenth century, no less than fifteen redactions of Aleksandr's Vita (Zhitie) were known.2 The earliest text, hereafter ANR, was written in the Rozhdestvenskii - i.e. dedicated to the Nativity of the Virgin (Rozhdestvo Bogoroditsy) - monastery shortly after the prince's death. (Begunov provides an extant text of the first redaction of the Vita, followed by a reconstruction of the original text.) ${ }^{3}$ One of the later vitae, written around 1547, was incorporated in Metropolitan Makarii's Great Menaion (Chet'i Minei), hereafter $A N M .{ }^{4}$ These two texts mark major points in the process of Aleksandr's canonization: the second half of the thirteenth century, when Aleksandr became the object of a local (Vladimir-Suzdal) cult, and 1547, when this cult was upgraded to national level. 5 The latter change coincided with Moscow's transformation from the center of a principality into the capital of the Tsardom of Muskovy.

The thirteenth century text starts with the usual humility topos, presenting Aleksandr as a son of Iaroslavl' and a grandson of Vsevolod (“Азъ худый и многогръшный, мало съмысля, покушаюся писати житие святого князя Олександра, сына Ярославля, а внука Всеволожа"). 6 The hagiographer does not make any further reference to the prince's genealogy. In ANR, Aleksandr is a "prince" (kniaz), only once is his title qualified by "Great" (Velikii). The resulting text is a mixture of hagiographic statements and epic discourse, which makes

2. See Iu. K. Begunov, "K voprosu ob izuchenii Zhitiia Aleksandra Nevskogo," Trudy otdela drevnerusskoi literatury, v. 17 (Moscow-Leningrad: Izdatel'stvo Akademii Nauk SSSR, 1961): 348. The author provides an extensive list of known redactions, both published and unpublished, up to 1961 .

3. Begunov presents the first redaction by providing the text from Pskov II chronicle accompanied by the known variations from other sources. See Iu. K. Begunov, Pamiatnik russkoi literatury XIII veka "Slovo o pogibeli russkoi zemli" (Moscow-Leningrad: Nauka, 1965): 158-180. The reconstructed original text is found ibid.: 185-194.

4. See V. Mansikka, Zhitie Aleksandra Nevskago: Razbor redaktsii i teksty (St Petersburg, 1913), annex, p. 15-31 ("Pamiatniki drevnei pismennosti" series, v. 180). The reader is also referred to the article on the Vita by V.I. Okhotnikova in D. S. Likhachev, ed., Slovar' knizhnikov i knizhnosti drevnei Rusi, v. I: XI - pervaia polovina XIV v. (Leningrad: Nauka, 1987): 354-363. A recent edition of the Vita can be found in L. A. Dmitriev and D.S. Likhachev, eds., Pamiatniki literatury drevnei Rusi, XIII v. (Moscow: Khudozhestvennaia literatura, 1981): 426-439.

5. A. S. Khoroshev, Politicheskaia istoriia russkoi kanonizatsii, XI-XVI VV. (Moscow: Izdatel'stvo Moskovskogo universiteta, 1986): 170, 172-174.

6. Iu. K. Begunov, Pamiatnik, op. cit.: 187. 
Aleksandr both a military saint and a holy ruler. Events in Aleksandr's life are given a universal value by Biblical references and divine intervention. The hagiographer also tells the story of Pelgui and his vision, in which he sees Boris and Gleb in a boat, Boris offering help to their relative Aleksandr ("да поможемъ сроднику своему Олександру"). ${ }^{7}$ The statement serves as a reminder that the saints Boris and Gleb are members of the prince's family. Thus, Aleksandr is a universal figure of Biblical proportions, as well as a local ruler closely bound to his land.

Aleksandr is presented as an exemplary prince in both religious and secular terms. He defends his faith no less than his land (he sends away representatives of the Pope, refusing conversion to Catholicism, unlike prince Daniil of Galich), never goes to battle without a blessing, and impresses foreign rulers not only with his strength, but also with his wisdom. As a true Christian ruler, Aleksandr becomes a monk shortly before his death. He enjoys divine support as a fighter for the religious cause, and the love of his subjects for being just and merciful. Six of those who fought with Aleksandr against the Swedes are named in ANR: Gavrilo Oleksich, Zbyslav Iakunovich, Iiakov, Misha, Sava, and Ratmir. Their courage is praised and their heroic deeds are described in detail.

According to Likhachev, this unusual combination of secular and religious components in the Vita can be explained by secular sources used by the author. Numerous similarities point to the Galich chronicle as a primary one. Importantly, the similarities between the Vita written in Vladimir and Galich tradition point to the linking figure of Metropolitan Kirill, who moved from Daniil, prince of Galich, to Aleksandr. ${ }^{8}$ Daniil and Aleksandr adopted different strategies regarding the Tartars and the Latin Church. Daniil accepted the Pope and rejected the Tartars, while Aleksandr, possibly under the influence of the Metropolitan, followed the diametrically opposed strategy. (The Tartars exempted the Church from taxation, thus making collaboration appealing to the ecclesiastic authorities.)

The very title of the sixteenth-century Vita points to a big change in the imagery. The previous laconic title (Житие святого князя Олександра) is extended to a long glorifying statement (Слово похвальное благовърному великому князю Александру, иже Невьскій именуется, новому чюдотвориу, въ немже и о чюдесъхъ его сповъдася). "Great" and "Nevskii" are now permanently attached to Aleksandr's name, and, as Mansikka comments, "the Vita is acquiring the character of a religious eulogy intended for edifying” (“житие приобретает характер церковно-ораторского творения, назначенного для назидания").$^{10}$

On the canonization list of 1547 for all-Russian veneration, Nevskii is the only prince among 13 new national saints. ${ }^{11}$ The author of the new Vita states that the

7. Ibid.: 189 .

8. D. S. Likhachev, "Galitskaia literaturnaia traditsiia," Trudy otdela drevne-russkoi literatury, v. 5 (Moscow-Leningrad: Izdatel'stvo Akademii Nauk SSSR, 1947): 36-56. See p. 49.

9. V. Mansikka, op. cit.: 15.

10. Ibid.: 109.

11. A. S. Khoroshev, op. cit.: 170. 
tsar and great prince of Russia Ivan Vasilevich was inspired by God to commemorate the great prince Aleksandr, and ordered Metropolitan Makarii to effectuate the task. Most commentators have agreed, however, that it was rather Makarii's own decision. Aleksandr stood as an important link in the chain of Russian rulers that went supposedly unbroken from Kiev to Moscow. Being a saint and a prince, his figure supported well the continuous genealogy argument used by Moscow in its struggle to unify other principalities under its central authority. It also fitted perfectly for the political exploitation of the "Third Rome theory" that followed its formulation in the first half of the sixteenth century. The latter has proven to be of an incredible success for it is still invoked five hundred years later.

$A N M$ reflects the transformation of Nevskii from a locally venerated saint to one of the patrons of the tsardom of all Russia. While ANR mentions only divine help in the battles and the funeral miracle, in ANM a list of posthumous miracles is supplemented. All but one are miracles of healing. The exception is the first miracle in which Aleksandr rises from the tomb to help his relative (srodnik) Dmitrii Donskoi. Shortly after that his relics are discovered untouched by decay and are transferred to a shrine (raka) that is said to have healing power. The simple statement about Aleksandr taking vows of schema (skhima), found in ANR, is extended in ANM into several lines. From the sixteenth century on, Aleksandr Nevskii clearly becomes a part of the monarchy's "gallery of founding fathers," but, in keeping with Makarii's line, as a holy man no less than a great prince.

The sixteenth-century Aleksandr differs from his thirteenth-century predecessor in several ways. His role as the protector of the Church is emphasized at the expense of his military achievements. The defender of several principalities becomes the patron saint of all Russia. This striking difference can be seen in Kirill's oration, pronounced after Nevskii's death. In the ANR version, Aleksandr's death is compared to the setting of the Sun of the Land of Suzdal ("уже зайде солнце земли Сужьдольской!") ${ }^{12}$ In ANM, it is the setting of the Sun of the Land of Russia (“уже бо зайде солнце земля Русскіа!"). ${ }^{13}$ When Aleksandr is included as one of the saints in The Great Menaion (Chet'i Minei), the number of people familiar with his image grows considerably since his Vita has to be read once per year in all churches. On the other hand, he has never become a patron of any particular activity, and thus would not be invoked by laymen in time of need. His cult has remained associated with central authority and political power.

The next major stage in this development comes in the eighteenth century, when Aleksandr's relics are translated by Peter the Great to the new capital. Nevskii can thus be seen as following in the footsteps of power: from Vladimir to Moscow, from Moscow to St. Petersburg. Feofan Prokopovich, a close associate of the tsar, pronounced in 1718 an Oration (Slovo) on Aleksandr Nevskii that sheds light on the reasons behind Peter's decision. A great part of Feofan's sermon concentrates on the necessity for each person to serve God according to his place. A ruler,

12. Iu. K. Begunov, Pamiatnik, op. cit.: 194.

13. V. Mansikka, op. cit.: 26. 
therefore, is holy when he fulfills his duties precisely as a ruler. Correspondingly, Aleksandr is holy because he fulfills his duties by ensuring the survival of the country. The great prince was fighting the internal enemy no less than the external one, setting an example followed by Peter - both in terms of territorial claims and internal reforms. Feofan calls Peter the living image (zhivoe zertsalo) of Aleksandr. ${ }^{14}$ A Synod statute of 1724 that prohibits presenting Saint Venerable Great Prince Aleksandr Nevskii on icons as a monk, prescribing the use of princely garments instead (“о воспрещении писать на иконах изображение Святого Благоверного Великого Князя Александра Невского в монашеских одеждах и о постановлении писать образ его в одеждах великокняжеских") ${ }^{15}$, makes official the change in emphasis with regard to the military and genealogical aspects of Nevskii's figure.

Shortly after Peter's death, Catherine I established the Order of St. Aleksandr Nevskii, completing her predecessor's decree. ${ }^{16}$ Unlike Peter, who had wanted it to be a strictly military award, she gave the new order for both military and civil service to the crown. A new trend that will continue well into the twentieth century is thus marked: Nevskii becomes more and more affiliated with the fulfillment of a patriotic duty of any kind.

If the medieval Vitae disguise the unpleasant sides of Nevskii's life, historical works of the nineteenth century present a more balanced picture. Nevskii's victories over the Swedes and Teutons as well as the argument with his brother Andrei over the principality of Vladimir (and his possible involvement in its destruction by the Tartars), which consequently drove Andrei abroad are both mentioned. Solov'ev talks about Aleksandr's role in bringing Tartar chislenniki to Novgorod. Even so, he justifies the prince's actions by the political situation and his desire to save the people from a greater evil (“отмолить людей от беды”). ${ }^{17}$ This line of thought is not new: the same conclusion was presented by the medieval texts. Solov'ev relies clearly on the sixteenth-century redaction, citing Kirill as referring to "The Sun of the Land of Russia” (“зашло солнце земли Русской”) and underlining "the religious significance of the Neva victory for Novgorod and the rest of Russia” (“то религиозное значение, которое имела Невская победа для Новгорода и остальной Руси”). ${ }^{18}$

The nineteenth century has added a powerful new concept to the national vocabulary: the Russian Idea. Historiography as well as intellectual controversy between the Westerners and the Slavophils has eventually crystallized the idea of a

14. Feofan Prokopovich, Sochinenia, ed. by I. P. Eremin (Moscow-Leningrad: Izdatel'stvo Akademii nauk SSSR, 1961): 102.

15. Velikii Kniaz' Aleksandr Nevskii, comp. by A. Iu. Karpov (Moscow: Russkii mir, 2002): 220 .

16. She is also the author of Zhizn' Aleksandra Nevskogo, bez chudes. See Iu. K. Begunov, "K voprosu...," art. cit.: 349 .

17. S. M. Solov'ev, Istoriia Rossii s drevneishikh vremen, 29 vols. in 15 (Moscow: Izdatel'stvo sotsial'no-ekonomicheskoi literatury, 1959-1966), v. II-3: 160.

18. Ibid.: 160,153 
unique Russian niche among nations and its unique path in universal history. This emphasis on an independent and unequalled national identity bears a resemblance to Moscow's religious claims as the Third Rome. At the same time, the Tartar yoke has assumed its fixed role of an evil to be blamed for all Russian backwardness, while Russia has been placed firmly into the role of a martyr saving Europe from the Tartar aggression.

The changes in the image of Aleksandr Nevskii during the imperial period trace a cyclical movement back to military discourse and political reasoning. The prince becomes a legendary figure assigned a set of fixed political and religious roles. Those roles are emphasized or underplayed depending on the particular balance of power at a given time. The new trait added to the image is that of a wise statesman, capable of finding a compromise, when necessary. Notably, Nevskii remains a saint representing the power, most likely familiar only to the literate upper class.

The Soviet period of Russian history is often seen as a decisive break with Russia's pre-revolutionary past. If this were so, one would expect the image of Nevskii to undergo fundamental change. In the 1920s it did, but very briefly. By the late 1930s, the image was restored to its former glorious position. Entries on Nevskii in the Entsiklopedicheskii slovar' published by Brokgauz and Efron in 1890, and in the Bol'shaia Sovetskaia Entsiklopediia of 1926, 1950, and 1970 editions provide a telling comparison. ${ }^{19}$ It can be seen that the only decisive break occurs in the 1920s, as by the 1950s the old and familiar historical perspective comes back. Class-oriented ideology gradually adopted a national discourse, replacing by the late 1930 s a complete break with pre-revolutionary history with the myth of national continuity and the emphasis on national state building as an underlying "historical process."

Eizenshtein's Aleksandr Nevskii was made in 1938, as part of a massive nationalist campaign. The film was intended for mass distribution. In this respect, it is similar in its main purpose to a liturgical play: to propagate the message. As Eizenshtein put it: "The Soviet cinema aims primarily to educate the masses. It seeks to give them a general education and a political education; it conducts an extensive campaign of propaganda for the Soviet State and its ideology among the people."20 Importantly, the word "propaganda" has no negative connotation here; rather, it is a noble obligation.

The work on the film coincided with the preparation of new textbooks for secondary schools and universities that reflected the changes. Historians had to

19. See F. A. Brokgauz, I. A. Efron, Entsiklopedicheskii slovar', ed. by I. E. Andreevskii (St Petersburg: Semenovskaia Tipo-Litografiia, 1890), t. I: 390-392; Bol'shaia Sovetskaia Entsiklopediia, ed. by N. I. Bukharin et al. (Moscow: Aktsionernoe obshchestvo "Sovetskaia entsiklopediia," 1926), t. II: 167-168; Bol'shaia Sovetskaia Entsiklopediia, ed. by S. I. Vavilov et al., 2nd ed. (Moscow: Gosudarstvennoe nauchnoe izdatel'stvo "Bol'shaia Sovetskaia Entsiklopediia," 1950), t. II: 76-78; Bol'shaia Sovetskaia Entsiklopediia, ed. by A. M. Prokhorov et al., 3rd ed. (Moscow: Izdatel'stvo "Sovetskaia entsiklopediia," 1970), t. I: 408409 .

20. S. Eizenshtein, Notes of a Film Director, trans. by X. Danko (London: Lawrence and Wishart, 1959): 25. 
comply with the instructions given by the Central Committee which insisted, among other revisions, on giving more attention to the reign of Aleksandr Nevskii, to his military campaigns against the Teutons, and especially to the Battle on Ice. ${ }^{21}$ In 1939, the Istoriia SSSR textbook, intended for universities' History departments was published. Prior to the publication, there was a public discussion about the principles that ought to govern the writing of Russian-Soviet history. Eizenshtein, just as anyone else reading the Soviet press, would have been aware of these new trends. In his notes on the film, Eizenshtein does not name the historians he consulted, but clearly, the major textbook and the film made almost simultaneously had to express the "official" version of history. It can even be argued that the film served as a popularized version of the historical narrative - just like a theatrical representation of a Vita could make hagiography accessible to the illiterate and unsophisticated. Thus, on the one hand the viewer is presented with a narration pretending to be historically correct, and on the other hand - with a complete invention where each and every effect is carefully calculated.

It can be argued that rather than presenting a completely new stage on Nevskii's posthumous "path," the Soviet period turns back to the original medieval sources for some features and continues several trends from pre-existing intellectual discourse. In general, the shift is from God helping the ruler against the enemies of God to the people helping the ruler against the enemies of the people. The people, in its turn, is a re-defined concept that has lost its class connotation and has acquired a national one. The greatest and most important transformation occurs with regard to the audience. After Eizenshtein's film was re-released in 1941 (it had been banned due to the Molotov-Ribbentrop pact), Nevskii finally becomes a nationally recognized figure.

As it could be seen, the balance between the secular and religious parts of Nevskii's image fluctuates constantly. The only irrevocable change that reflects the creation of the centralized state and the national self-perception is the all-Russian importance given to the prince. Once he becomes a national figure in the sixteenth century, this role is never challenged again.

As paradoxical as it might seem, this patron of the nation, whether soldier or saint, becomes known to the nation with Eizenshtein's film. The film fulfills the task that Makarii set forth but could not achieve. Eizenshtein did not create a new perception; he used the one already in existence. The hagiographical model, readopted by contemporary historiography, serves as the main framework behind the modern rendering of the Vita. The artistic, the ethical, and the ritual play equally important roles.

Through the new medium, the image could be brought to the whole population, literate and illiterate alike. What has changed was not the content of the message, but its receiver. It can be argued that the film acted as a "cinema icon," accessible to

21. D. L. Brandenberger and A. M. Dubrovsky, “'The People Need a Tsar': The Emergence of National Bolshevism as Stalinist Ideology, 1931-1941," Europe-Asia Studies, 50:5 (July 1998): 873-892. See p. 879. 
all and bearing a straightforward meaning with the help of clearly defined good and evil. Thus, after becoming a "mass-hero," Aleksandr Nevskii became a "masssaint."

The problem of Aleksandr Nevskii's seemingly eternal existence in the national memory is in fact an illusory one. Instead of a constant presence, a series of "resurrections" can be traced; each of them connected to either an internal struggle for power, or to an external war. These changes in Nevskii's image seem to be in agreement with the initial proposition to see hagiography and national biography as two particular cases representing one ideological model.

Duke University

Durham, NC

USA

aen4@duke.edu 